„Bohemistyka” 2019, nr 4, ISSN 1642-9893

Milan HRDLIČKA

DOI: $10.14746 /$ bo. 2019.4 .3

Univerzita Karlova

\section{Morfologická forma a její význam ${ }^{1}$}

Keywords: form, grammar, linguodidactics, onomasiology, semasiology, Czech language textbooks for foreigners, meaning

Klíčová slova: forma, gramatika, lingvodidaktika, onomaziologie, sémaziologie, učebnice češtiny pro cizince, význam

\section{Abstract}

When language units are analysed the relation between the form and meaning is investigated. Looking at quality of the relation, linguists study if, and possibly also how, the semantic component is reflected in the formal realization. The relation between the form and meaning is arbitrary and conventional. Focusing on the quantitative aspect of relation between form and meaning, the ratio of a form to the number of its meanings is studied. One form may have several meanings. Some forms have the same or similar meaning, however they usually differ in frequency of use, style or there is a subtle semantic variation. There are two approaches: semasiological (which is predominant in description of Czech for foreigners) and onomasiological which offers new possibilities for the description of Czech grammar system.

Při rozboru jazykových jednotek se sleduje vztah mezi formou a mezi obsahem. Pokud jde o kvalitu daného vztahu, lingvisté zkoumají, zda, event. jakým způsobem se významová složka promítá do své formální realizace. Vztah mezi formou a významem je arbitrární a konvenční. Pokud jde o kvantitativní stránku vztahu forma - význam, sleduje se poměr mezi formou a počtem významových jednotek. Určita forma může vyjadřovat více významů. Některé formy mají stejný nebo podobný význam, často se však liší frekvencí, stylem, významovými nuancemi. Popisuje se rozdíl mezi př́stupem sémaziologickým (ten v popisu češtiny pro cizince dominuje) a onomaziologickým, který nabízí nové možnosti popisu mluvnického systému češtiny.

${ }^{1}$ Tato studie vznikla za podpory projektu Univerzity Karlovy Progres Q10, Jazyk v proměnách času, místa, kultury.
Při analýze jednotek znakového charakteru se sleduje vztah mezi jejich formou (označujícím) a významem (označovaným $)^{2}$. Důležitou součást problematiky představuje kvalitativní a kvantitativní aspekt uvedené relace.

Pokud jde o kvalitativní dimenzi, zkoumá se, zda (event. jakým způsobem) se významová složka promítá do svého formálního ztvárnění. V mnoha případech tomu tak není, zmíněná relace má arbitrární podobu, vztah forma - význam je nahodilý, bez prŕíčinné souvislosti. V jazycích je tedy pro tutéž skutečnost (týž denotát) odlišné pojmenování (pes - dog - Hund - chien - sobaka), které o její povaze (tedy o označovaném) nic relevantního nevypovídá3.

Vztah mezi formou a významem má současně povahu konvenční, je pro příslušné jazykové společenství závazný, ustálený, zažitý. V opačném př́ipadě by to pro úspěšnou komunikaci představovalo zásadní překážku. Národní jazyk se přejímá po předcích, není ovšem neměnný, stále týž. Naopak: jazyk se vyvíjí ${ }^{4}$, jeho podoba je však relativně ustálená. Celý proces připomíná postupně, dílčím způsobem se měnící kontinuum. Mathesius (1932) výstižně hovoří o pružné stabilitě jazyka. Zajímavou otázku pokroku v jazyce nastoluje Skalička (1960): spočívá ve směřování k jednoduchosti, pravidelnosti, či v tendenci ke složitosti, obtížnosti, stylové rozrůzněnosti a variantnosti?

\footnotetext{
${ }^{2}$ Vycházíme ze saussurovského (bilaterálního) pojetí, z jednoty formy a význa$\mathrm{mu}$. V pojetí unilaterálním se znak chápe pouze jako forma (jde o zvukový/grafický útvar, který je v konvenčním vztahu s prvkem reality). Mezi vlastnosti jazykového znaku patří materiální povaha (napsání, vyslovení) diskrétnost, stabilnost (pevný tvar, rozsah), lineárnost (jednorozměrná podoba, začátek a konec), prenosnost $\mathrm{v}$ čase a prostoru, sémantičnost (účelnost, vztah $\mathrm{k}$ funkci a/nebo významu), duálnost (členění na figury, které znakový charakter nemají) a další, Čermák 2004, Erhart 1984. Z lingvodidaktického hlediska je významná jeho naučitelnost.

${ }^{3}$ Odhlížíme od př́buznosti jazyků, srov. české mléko, slovenské mlieko, ruské moloko atd.

${ }^{4}$ Máme na mysli jak různé tempo vývoje (odbobí stagnace, úpadku proti epochám vzestupu, rozvoje), tak odlišný rytmus a rozsah změn jazykových rovin: nejrychleji se vyvíjí rovina lexikální, na rovině zvukové (a grafické) i gramatické zaznamenáváme vývoj výrazně pomalejší a v omezenějším rozsahu.
} 
Je třeba upozornit na rozdíl mezi arbitrárností ${ }^{5}$, která je součástí obecné teorie znaku, a (ne)motivovaností pojmenování spadající do lexikologie. Pojmenování se dělí na značková, nemotivovaná (pes, bílý, mluvit) a na odvozená, motivovaná (pejsek, psiček, psí, psưv; bělouš, běloba, vybílit; mluva, výmluvný, mluvněji, premluvit, odmlouvat). Ta v jazyce výraznou měrou převažují ${ }^{6}$. Kauzálnost, jistá strukturní motivace (Dolník 2009), se projevuje při flexi (psa, psovi, psem, psi, psů; bílý, bílou, bělejší; (ne)mluví, mluvil, mluvil by, mluv!, bude mluvit aj.).

Co se kvantitativní stránky vztahu forma - význam týče, předmětem zájmu je poměr mezi formou a počtem významových jednotek, který nebývá jedna ku jedné.

Forma může na rovině mluvnické i lexikální ${ }^{7}$ vázat několik významů : tvar pána vyjadřuje genitiv a akuzativ singuláru tvrdého životného maskulina, forma mluví tretí osobu singuláru a plurálu indikativu prézentu, je je tvar třetí osoby singuláru indikativu prézentu slovesa být a současně akuzativ osobního zájmena oni.

V komunikaci se setkáváme s př́pady neutralizace, resp. s projevy příznakovosti (formě odpovídá určitý význam, např. tvar množného

${ }^{5}$ Za výjimku jsou považována zvukomalebná citoslovce (bum, cvak, žbluňk, prásk). I to je problematické - týž zvuk bývá zachycován odlišným, a přitom ustáleným způsobem: české kikiriki má paralelu v ruském kukarěku, francouzském kokoriko, anglickém kokudúdldu (cock-a-doodle-do) atd.

${ }^{6}$ Hrbáček (1999, s. 46) upozorňuje, že i mnohá slova, která se zdají být nemotivovaná, jsou výsledkem motivovanosti: stůl - stlát, medvěd - meduěd, strom - strmy apod.

${ }^{7}$ Hovoří se o homonymii (slova se stejnou zvukovou a/nebo grafickou podobou a odlišným, nepř́buzným významem: kolej z latinského collegium - ubytovací zařízení pro studenty versus kolej - od slova kolo, dráha pro vlak, tramvaj) a o polysémii založené na podobných významech $\mathrm{v}$ důsledku metafory (jazyk $\mathrm{v}$ ústech kontra jazyk u boty, sněhové jazyky na vozovce) nebo metonymie (Čte Hrabala).

${ }^{8}$ Je zajímavé sledovat nekorespondenci formy a významu (náhrobní nápis Odpočivej v pokoji nevyjadřuje rozkaz) či porušení jejich shody (Ty kluku ušatá! Ty chlape liná!), event. okrajové př́ípady uplatnění (ne)životných koncovek (Ledoborce pluly $\mathrm{x}$ Ledoborci pluli; Našel hřiba x hřib). čísla studenti plurál skutečně vyjadřuje) a bezpříznakovosti ${ }^{9}$ (forma má podle kontextu významy dva, event. více). Tvar jednotného čísla ve výpovědi Studuje český jazyk koresponduje s významem, ve výpovědi Studuje český a německý jazyk nikoliv, v ní týž tvar vyjadřuje plurál. Bezpříznakovost činí jinojazyčným mluvčím značné potíže, především př́i studiu slovesného vidu. Forma imperfektiva překládal zachycuje děj, proces, nedosažení výsledku (Ten text jsem prekládal týden - mluvčí text nepřeložil, byl př́liš obtížný, dlouhý) stejně jako završení děje, rezultát: mluvčí poukazuje na náročnost své aktivity, jeho záměrem je získat větší honorár̆, více času na další překlad.

$\mathrm{V}$ jazyce dochází k četným případům, kdy určitý význam může být vyjádřen vícero variantními (konkurečními, synonymními) formami.

Některá formální vyjádření (morfologická i syntaktická) ${ }^{10}$ jsou rovnocenná, v podstatě volně zaměnitelná ${ }^{11}$ (po otcovu $\mathrm{x}$ otcově odjez$d u$; Řekl mu, at' to udélá $\mathrm{x}$ aby to udělal $\mathrm{x}$ že to má / musí udélat; těch lidi! x tolik lidi!; nech $\mathrm{x}$ nechej, neplač x neplakej, za války $\mathrm{x}$ během války; přes les x lesem). Častěji se však variantní vyjádření liší: četností výskytu, stylovou charakteristikou, pozicí v rámci spisovné češtiny (čěšu x češi x česám, rozumí x rozumějí, Angličané x Angličani, tři x třech, oblékl x obléknul, méně x miń, mou x moji knihu, shromažd'te se $\mathrm{x}$ shromážděte se, $i$ když $\mathrm{x}$ prestože $\mathrm{x}$ ač $\mathrm{x}$ ačkoliv $\mathrm{x}$ třebaže $\left.\mathrm{x} b y t^{\prime}\right)$.

Odlišné může být jejich umístění na ose spisovnost - nespisovnost, event. i na rovině mluvenost - psanost (před dvěma hodinami x dvou-

\footnotetext{
${ }^{9}$ Tato Jakobsonova teorie je známa i jako teorie binárních protikladů (Černý 1998)

${ }^{10}$ Srov. Počkám tu, až přijdeš x Počkám tu, dokud nepřijdeš; Po př́iezdu zavolal $\mathrm{x}$ Když prijel, zavolal; Četla zajímavou knihu x Četla knihu, která byla zajímavá; Budu-li mit čas / Mít čas / Jestli (jestliže, pokud, když, pakliže) budu mít čas, pưjdu do kina atd.

${ }^{11}$ Někdy může být volná zaměnitelnost pouze zdánlivá: řekne-li se Zavřeli ho za krádež, má se na mysli postih, trest, následek nežádoucí činnosti, kdežto výpověd Zavřeli ho pro krádež vyjadřuje příčinu, důvod zatčení: zavřeli ho, nebot' dotyčný kradl.
} 
ma hodinama, koupili bychom x koupili bysme, román je přeložený $\mathrm{x}$ přeloženej) i další rysy. Patří mezi ně nestejná míra zdvořilosti a důrazu (Pište! Budete psát! Psát! Koukejte psát! Kdybyste raději psali... Tak píšeme, pišeme!), archaizující ráz promluvy (Neřekl ani slova, Mával na ni cosi volaje), jiná míra expresivity (Uhodil tuhý mráz x Uhodily tuhé mrazy), intenzity děje (Jezdila tam auta $\mathrm{x}$ Jezdilo tam auto za autem) nebo kvantity (Babička upekla buchty $\mathrm{x}$ napekla buchty x napekla buchet).

Jindy jde o funkční využití jistých formálních omezení - při užití zvratného trpného rodu nelze vyjádřit původce děje, zůstává nepojmenován (Včera o tom bylo rozhodnuto ministrem financí x Včera se o tom rozhodlo).

V komunikaci nacházíme mezi variantními formami další rozdíly: mezi vazbou slovesa s lokálem (Mluvíme o mostu) a významem místním (Stojíme na mostě), mezi individualizací (otcův dům) a generalizací (diom otce) či životností a neživotností (Čekáme na něho, pouze pro rod mužský životný x na něj, platí pro rod mužský životný i neživotný $)^{12}$, mezi vlastností stálou (Je zpěvák; Jsem zvědavý) a přechodnou (Je zpěvákem; Jsem zvědav, jak to dopadne) atd.

Naznačili jsme, že je mluvnický systém ${ }^{13}$ češtiny mimořádně propracovaný ${ }^{14}$ a obtížný, a to i ve srovnání se slovanskými jazyky. Vyznačuje se velkým počtem deklinačních a konjugačních paradigmat, různými typy deklinace, značným množstvím nepravidelností a výjimek, bohatou variantností formálních prostředků (Hrdlička 2014).

${ }^{12}$ Někdy může jít o rozlišení sémantické: $n a$ východě republiky x při východu slunce, zaznamenáváme i četné další př́pady, kupř. manželé (manželský pár, muž a žena, event. ženatí muži) x manželové (pouze ženatí muži); o Češich (kolokviálně o Čechách) - o obyvatelích Čech x o Čechách (o území Čech), o plechách (plech) x o plešich (pleš), o hrušce x o panu Hruškovi atd.

${ }^{13}$ Obdobnými rysy se vyznačuje také plán syntaktický, srov. otázku sémantických skladebních vztahů (predikace, determinace, koordinace, apozice) a jejich formálně-syntaktického vyjádření (hypotaxe: kongruence, rekce, adjunkce; parataxe).

${ }^{14} \mathrm{U}$ českého slovesa napočítáme 413 potenciálních tvarů (Hausenblas, Kuchař 1974, s. 375).
V zájmu jeho adekvátního osvojení je nutné hledat schůdná a účinná lingvodidaktická řešení.

Ke vztahu forma - význam se přistupuje i z perspektivy jejich vzájemného poměru, resp. pořadi ${ }^{15}$. Dostáváme se tím ke dvojici bázových protichůdných koncepcí popisu mluvnického systému: k př́ístupu sémaziologickému (postupuje se od formy k jejímu významu, zjišt'uje se, kolik významů se váže na určitou formu, o jaké významy se jedná, v jakém jsou vztahu) a onomaziologickému ${ }^{16}$ (vychází se směrem opačným, od významu k jeho formálnímu ztvárnění, sleduje se, kolik forem jistý význam vyjadřuje, o které formy jde a jaké jsou mezi nimi relace).

Dřive než uvedeme charakteristiku oněch bipolárních konceptů, naznačíme rozdíly mezi pozicí rodilého a jinojazyčného mluvčího v procesu nabývání znalosti českého morfosyntaktického kódu.

Rodilý mluvčí získává v raném věku znalost češtiny osvojováním, intuitivní cestou, spontánně, kontaktem s rodilými mluvčími češtiny, nápodobou jejich mluvy, tedy bez učení se jazykovým pravidlům. $\mathrm{V}$ průběhu následného institucionálního vzdělávání u něho dochází $\mathrm{k}$ postupnému rozvíjení a prohlubování poznatků o jazyce, $\mathrm{k}$ jejich usouvztažňování, trrídění. Dostává se mu poučení o pojmosloví, o formálním a funkčním tvarosloví prestižní variety ${ }^{17}$ (učí se méně frekventovaným tvarům, flexi zájmen týž, jenž a číslovek, tvoření př́čestí trpného aj.), o syntaxi (větné členy ${ }^{18}$, typy souvětí, poměr mezi větami hlavními, druhy vět vedlejších).

${ }^{15} \mathrm{~V}$ tomto př́padě je možný i přístup mezijazykový - hledání korespondencí, ale i substitucí tzv. neparalelních gramatických kategorií a jevů. Zmiňujeme v tomto smyslu slovanský slovesný vid a bohatý systém časů $\mathrm{v}$ jazycích románských, germánských aj., neexistenci členu určitého a neurčitého v češtině a jeho náhradu zájmenem ukazovacím (ten) a neurčitým (některý, nějaký) apod.

${ }^{16} \mathrm{Z}$ prostorových důvodů zde neuvažujeme o dalších relevantních dichotomiích, o opozici deskripce - preskripce a indukce - dedukce.

${ }^{17}$ Pochopitelně též o lexikálním, morfologickém a syntaktickém pravopise spisovné češtiny.

${ }^{18} \mathrm{~V}$ této oblasti je ovšem nemálo problémových míst, kupř. poznávání významů př́slovečných - zřetele (V kráse nemá konkurenci. Ta zeměje bohatá na ropu.) apod. 
S významem morfologických prostředků větší potíže nemívá, i když nemusí vždy náležitě rozlišovat rozdíl mezi číslovkami souborovými (dvoje prázdniny, troje dveře) a druhovými (dvojí prázdniny, troji dveře), základními (čtyři roční obdobi) a úhrnnými (čtvero ročních obdobi), nuancemi ve spojeních Přijeli k nám o víkendu (čas) $\mathrm{x}$ na víkend (účel) atd.

Role jinojazyčného mluvčího bývá dosti odlišná. Může se češtině učit (i si ji osvojovat) ${ }^{19}$, což na něho klade mimořádné nároky. Slované mívají menší potíže s porozuměním (dochází však u nich k četným prrípadům interference), Neslované, zejména mimoevropští, s typologicky odlišnou mateřštinou, potřebují oporu ve srozumitelných a explicitních návodech přibližujících nejen stránku formální, ale také řečovou (význam, funkci forem v textu). Ty v učebnicích mnohdy chybí nebo jsou nedostačující (Hrdlička 2009). Převažuje v nich orientace na stránku formální do té míry, až přerůstá ve formalismus - cizinec se kupřr. naučí, že po předložce do následuje jméno v genitivu, zpravidla však netuší, v kterých kontextech a významech ji má použít.

V popisech mluvnického systému češtiny měl doposud monopolní postavení přístup sémaziologický. Nepochybně proto, že je významová dimenze (funkce) gramatických kategorií a jevů rodilému mluvčímu zřejmá; potíže mu činí především osvojování kodifikovaných tvarů prestižní variety národního jazyka. Roli jistě sehrává i tradice, určitá lingvistická a lingvodidaktická setrvačnost, stejně jako skutečnost, že jsou gramatické kategorie z tohoto zorného úhlu na první pohled snadněji uchopitelné, jejich kontury jsou zřetelně vymezené, zdají se být jednoznačnější, konkrétnější (srov. uplatnění nepoměrně amorfnější sémantiky při popisu systému českých pádů).

Domníváme se, že by řešení stávající situace mohl účinně napomoci př́stup onomaziologický, resp. podstatně vyváženějšši ${ }^{20}$ a rovno-

\footnotetext{
${ }^{19}$ Pro zjednodušení odhlížíme od některých relevantních faktorů, od skutečnosti,
} zda se jedná o Slovana, či Neslovana, o mateřštinu indoevropskou, nebo neindoevropskou, o učení se v zahraničí, nebo $\mathrm{v}$ autentickém cizojazyčném prostředí apod.

${ }^{20}$ Chceme $\mathrm{v}$ této souvislosti zdůraznit nutnost koexistence obou př́istupů. $\mathrm{V}$ počátečních fázích nabývání znalosti jinojazyčného kódu hraje sice důležitější roli stránka právnější zastoupení obou koncepcí. To ostatně navrhuje Dolník (1993), který uvažuje o globálně pojímané modifikované lingvistické gramatice, pro niž by byl příznačný popis formální, formálně-sémantický, sémantický i sémanticko-formální.

V cizojazyčné výuce je podle našeho soudu nosné vycházet od obdobných (relativně společných) významů, od jazykových univerzálií (hloubkových struktur), tedy od momentů, které jazyky spojují, a směřovat $\mathrm{k}$ jejich nekonečně pestrému a různorodému kaleidoskopu formálních (morfosyntaktických) realizací v jednotlivých jazykových kódech. Dolník komentuje situaci slovy:

Univerzálna gramatika ako systém princípov je teda obsahom geneticky určenej jazykovej schopnosti a gramatika istého prirodzeného jazyka parametrickou exemplifikáciou týchto princípov. Pravidlá gramatiky jednotlivých jazykov sú odvodené z univerzálnych princípov (Dolník 2009, s. 199).

Bezpochyby by se tak vytvořil patřičný prostor pro přehlednou prezentaci konkurenčních forem vyjádření. Daný koncept by v daleko větší míře bral v potaz onu zanedbávanou dimenzi řečovou, poskytoval by též současně náležitou oporu pro popis a výklad tzv. neparalelních gramatických kategorií a jevů (Hrdlička 2008).

V oblasti češtiny jako nemateřského jazyka je, bohužel, z této perspektivy prrípadné hovořit o poli neoraném. Věříme však, že se situace začne v dohledné době měnit $\mathrm{k}$ lepšímu.

\section{Literatura}

Č e r má k F., 2004, Jazyk a jazykověda, Praha: Karolinum. Č e r ný J., 1998, Úvod do studia jazyka, Olomouc: Rubiko.

D o 1 ník J., 1993, Gramatika slovenčiny pre vyučovanie cudzincov. In: J. Mlacek (ed.), Studia Academica Slovaca, Bratislava: Stimul, s. 62-70.

D o lník J., 2009, V̌̌eobecná jazykoveda. Opis a vysvetlovanie jazyka, Bratislava: Veda.

významová (viz „komunikativnost” agramatických vyjádření typu Kino včera jít já), pouhá znalost gramatických pravidel a forem bez lexikálního výraziva se míjí účinkem, záhy však musí začít docházet $\mathrm{k}$ jejich náležitému zastoupení (o úzkém sepětí gramatiky a slovníku hovoří již de Saussure). 
E r h a r t A., 1984, Základy jazykovědy, Praha: Státní pedagogické nakladatelství.

H a u s e n b l a s K., K u c h a ř J . a kol., 1974, Čeština za školou, Praha: Orbis.

H r b á č e k J., 1999, Úvod do studia jazyka, Praha: FF UK.

H rdli čk a M., 2008, K otázce výkladu ,,neparalelnich“ gramatických kategorii a jevì. In: J. Hasil (ed.), Čeština jako jazyk cizí V. Materiály z V. Mezinárodního sympozia o češtině jako cizím jazyku, Praha: FF UK, Euroslavica, s. $63-69$.

H r d li č k a M., 2009, Gramatika a výuka češtiny jako ciziho jazyka. K prezentaci české gramatiky v učebnicich češtiny pro cizince, Praha: Karolinum.

H r d li č k a M., 2014, K prezentaci české deklinace jinojazyčným mluvčím, ,Studie z aplikované lingvistiky" 5, č. 2, s. 98-115.

M a th e s i u s V., 1932, O požadavku stability ve spisovném jazyce. In: B. Mathesius, M. Weingart (eds.), Spisovná čeština a jazyková kultura, Praha: Melantrich, s. 14-31.

S k a li č k a Vl., 1960, Vývoj jazyka, Praha: Státní pedagogické nakladatelství. 